\title{
Penghematan Gas H2 Pada Sistem PEMFC (Proton Exchange Membrane Fuel Cell) Sesuai Perubahan Daya Beban
}

\author{
Saving Gas System H2 PEMFC (Proton Exchange \\ Membrane Fuel Cell) According to Changes in Power Load
}

\author{
Habibullah
}

Jurusan Teknik Elektro Universitas Negeri Padang Email : hbullah@ gmail.com

\begin{abstract}
This project aims to testing the equation which obtained from the graph characteristics relationships of the optimum input voltage driver valve to change the power load on the valve opening proportional to the input PEMFC system so that the valve opening will work automatically according to changes in load power. Equations are taken there are two linear equations and polynomials. Enter the equation is used as the power load and input voltage output driver valves.

Test results show similarities with both voltage and output current characteristics are almost the same system with the characteristics of the optimum and maximum valve opening. H2 gas usage on testing with both equations show similar values with optimum valve opening, making it more efficient than the maximum valve opening.
\end{abstract}

Keywords : PEM Fuel Cell, Proporsional valve, H2 gas

\section{PENDAHULUAN}

Pada fuel cell, konversi energi terjadi dengan adanya reaksi elektrokimia dari bahan bakar (hidrogen) dan oksidan (oksigen) yang akan mengubah energi kimia fuel menjadi energi listrik(Muzamir Isa dkk, 2006: 2134-2135). Tegangan keluaran yang dihasilkan oleh fuel cell juga dipengaruhi oleh adanya rugi-rugi dari proses yang terjadi, baik dari proses kimia maupun mekanis. Karakteristik dari sistem fuel cell adalah tegangan yang dihasilkan akan semakin menurun jika terjadi pertambahan beban. Untuk mengatasinya biasanya tekanan gas $\mathrm{H} 2$ diatur pada tekanan maksimumnya, sesuai dengan kapasitas fuel cell tersebut. Tujuannya supaya suplay gas $\mathrm{H} 2$ tetap memadai jika beban tiba-tiba membesar.

Pada sistem PEMFC H-100 suplay gas H2 nya diberikan pada tekanan yang maksimum, yaitu antara $5.8 \mathrm{psi}-6.5 \mathrm{psi}(\mathrm{H}-$ 100 Fuel Cell Stack User Manual, V2.0, 2009). Tekanan ini sebenarnya dapat disesuaikan dengan besar beban yang terhubung ke sistem, pada saat bebannya kecil tekanan gas yang diberikan juga kecil, dan sebaliknya jika beban besar maka tekanannya juga diperbesar, sehingga dapat menghemat pemakaian gas $\mathrm{H} 2$.

Tegangan masukan valve didapatkan dari sebuah driver yang dibangun dari rangkain op-amp. Masukkan driver ini diatur secara manual pada setiap perubahan daya beban.

Untuk memperbesar atau memperkecil tekanan gas $\mathrm{H} 2$ yang masuk ke sistem PEMFC ini maka ditambahkan suatu valve proporsional pada masukan sistem. Besar bukaan valve akan ditentukan besarnya oleh beban yang terhubung. Berdasarkan hasil dari penelitian sebelumnya yang menghasilkan grafik karakteristik hubungan tegangan optimum input driver valve terhadap daya beban maka dirancang pengaturan bukaan valve input gas $\mathrm{H} 2$ pada sistem PEMFC secara otomatis sesuai dengan perubahan daya beban menggunakan persamaan yang didapatkan dari grafik karakteristik tersebut.

Dengan pengaturan seperti ini maka kebutuhan gas $\mathrm{H} 2$ pada sistem PEMFC dapat dioptimalkan sehingga dapat menghemat pemakaian gas $\mathrm{H} 2$ tanpa mengurangi performa keluaran sistem. 
Penelitian ini bertujuan untuk mengoptimalkan kebutuhan gas $\mathrm{H} 2$ pada sistem PEMFC dengan cara mengatur aliran gas $\mathrm{H} 2$ pada sistem PEMFC $\mathrm{H}-100$ secara otomatis sesuai dengan persamaan pada karakteristik hubungan tegangan optimum input driver valve terhadap daya beban sehingga pemakaian gas $\mathrm{H} 2$ lebih hemat tanpa mengurangi performa keluaran sistem.

Penelitian ini membahas rancangan pengaturan bukaan valve proporsional pada input sistem PEMFC H-100 secara otomatis sesuai persamaan pada karakteristik hubungan input driver optimum terhadap daya beban. Ada dua pendekatan persamaan yang akan diujikan, yaitu pendekatan dengan persamaan polinomial dan pendekatan dengan persamaan linier.

Kedua persamaan diujikan pada sistem PEMFC H-100 dan hasilnya akan dibandingkan dengan hasil percobaan sebelumnya. Dari hasil pengujian akan dicari efisiensi sistem dan dibandingkan dengan efisiensi sistem pada percobaan sebelumnya.

\section{Fuel Cell}

Fuel cell adalah alat konversi elektrokimia yang berfungsi mengubah energi kimia dari fuel (bahan bakar) menjadi energi listrik. Sama halnya dengan baterai yang menghasilkan listrik melalui proses elektrokimia perbedaan fuel cell dengan baterai adalah karena fuel cell menghasilkan air dan panas di samping energi listrik. Fuel cell dapat menghasilkan energi secara berkelanjutan (kontinyu) karena sumber energinya diberikan langsung dari sumber di luar sistem, sedangkan pada baterai sumber energi bersatu dengan sistem, sehingga jika sumber energinya habis, maka harus dilakukan pengisian sumber energi lagi (Muzamir Isa dkk, 2006: 2134-2135).

Tiap unit sistem fuel cell terdiri atas 4 komponen utama, yaitu:

1. Anoda (fuel electrode) yaitu komponen yang menjadi tempat untuk bertemunya fuel dengan elektrolit.

2. Katoda (oxygen electrode) yaitu komponen yang menjadi tempat untuk bertemunya oksigen dengan elektrolit.

3. Elektrolit yaitu bahan yang berfungsi sebagai penghantar yang mengalirkan ion yang berasal dari bahan bakar di anoda menuju katoda.

4. Katalis yaitu material atau bahan khusus untuk mempercepat reaksi kimiawi atau reduksi-oksidasi

Untuk mampu menghasilkan tegangan yang tinggi/yang dinginkan maka sel tersebut dihubungkan secara seri. Kumpulan dari banyak sel tunggal ini disebut stack. Untuk membuat stack, selain dibutuhkan sel tunggal, juga diperlukan sel separator. Susunan sebuah Fuel Cell dapat dilihat pada gambar 1.

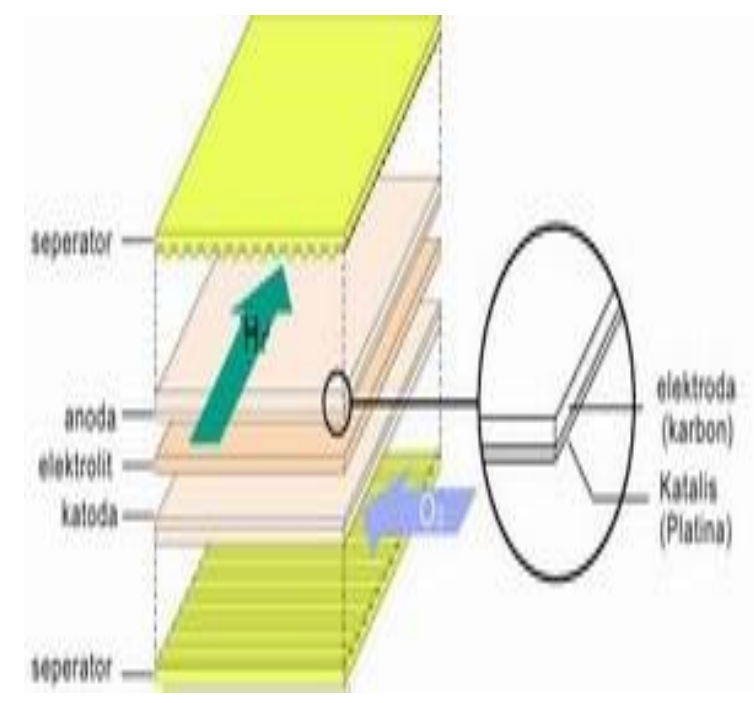

Gambar 1. Unit Fuel Cell

(Sumber: Aryani, Dharma, 2008)

\section{Prinsip kerja fuel cell}

Saat elektroda dihubungkan dengan beban dari luar, maka proses yang terjadi adalah sebagai berikut; Hidrogen $(\mathrm{H} 2)$ yang menyentuh permukaan anoda akan bereaksi secara kimiawi (reduksi), menghasilkan ion hidrogen $\left(\mathrm{H}^{+}\right)$dan ion elektron $\left(\mathrm{e}^{-}\right)$. Sedangkan pada katoda terjadi reaksi oksidasi, menghasilkan air. Ion hidrogen $\left(\mathrm{H}^{+}\right)$ akan bergerak dari permukaan anoda menuju katoda melalui elektrolit dan ion elektron $\left(\mathrm{e}^{-}\right)$ bergerak ke beban lalu menuju katoda. Prinsip kerja sebuah fuel cell dapat dilihat pada gambar 2 dan jenis-jenis fuel cell 
berdasarkan reaksi pada anoda dan katodanya dapat dilihat pada tabel 1.

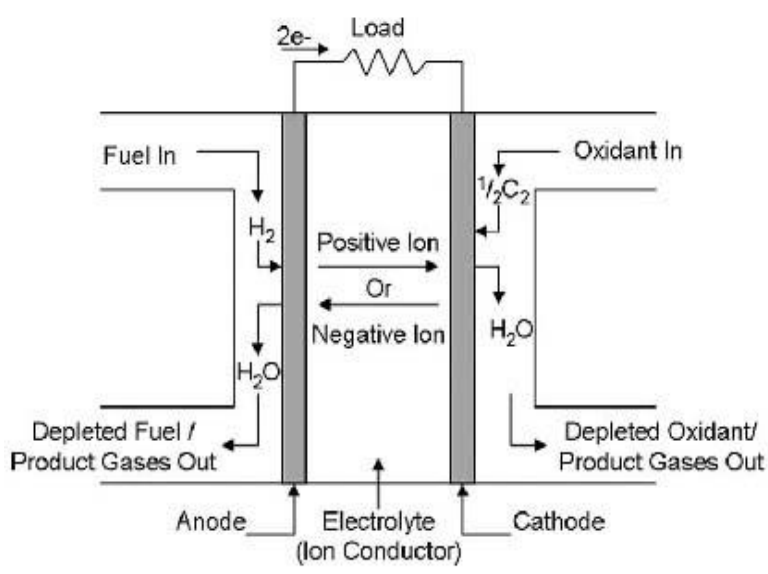

Gambar 2. Prinsip kerja Fuel Cell

(Sumber: Aryani, Dharma, 2008)

\section{PEMFC}

PEMFC (Proton Exchange Membrane Fuel Cell) ini bekerja pada temperatur operasi yang rendah $\left(50^{\circ}-120^{\circ}\right)$ dengan menggunakan bahan bakar hidrogen murni. Jenis membran yang digunakan adalah Nafion. Nafion memiliki sifat sebagai konduktor dan melewatkan muatan positif $\mathrm{H}^{+}$.

Katalis PEMFC umumnya menggunakan bahan dasar platina. Jenis fuel cell ini yang akan diuji dan diatur masukan gas $\mathrm{H} 2$ nya dalam penelitian ini.

\section{Karakteristik PEMFC}

Polymer electrolyte membrane fuel cell (PEMFC) disebut juga proton exchange membrane fuel cell. Membrane ini berupa lapisan tipis padat yang berfungsi sebagai elektrolit pemisah katoda dan anoda. Membran ini secara selektif mengontrol transport proton dari anoda ke katoda dalam fuel cell. PEMFC mengandung katalis platina. Untuk menhasilkan energi, PEMFC hanya memerlukan hidrogen, oksigen dan udara, serta air untuk mengoperasikannya. Selain itu, pada fuel cell ini tidak dipakai fluida yang bersifat korosif seperti jenis fuel cell lainnya.

Tabel 1. Reaksi elektrokimia Fuel Cell

\begin{tabular}{|c|c|c|}
\hline Fuel Cell & $\begin{array}{c}\text { Reaksi pada } \\
\text { Anoda }\end{array}$ & $\begin{array}{c}\text { Reaksi pada } \\
\text { Katoda }\end{array}$ \\
\hline $\begin{array}{l}\text { Proton } \\
\text { Exchange } \\
\text { Membrane } \\
\text { dan } \\
\text { Phosporic } \\
\text { Acid }\end{array}$ & $\mathrm{H}_{2} \rightarrow 2 \mathrm{H}^{+}+2 \mathrm{e}^{-}$ & $\begin{array}{l}\frac{1}{2} \mathrm{O}_{2}+2 \mathrm{H}^{+} \\
+2 \mathrm{e}^{-} \rightarrow \mathrm{H}_{2} \mathrm{O}\end{array}$ \\
\hline Alkaline & $\begin{array}{l}\mathrm{H}_{2}+2(\mathrm{OH})^{-} \rightarrow \\
2 \mathrm{H}_{2} \mathrm{O}+2 \mathrm{e}^{-}\end{array}$ & $\begin{array}{l}\frac{1}{2} \mathrm{O}_{2}+\mathrm{H}_{2} \mathrm{O} \\
+2 \mathrm{e}^{-} \rightarrow \\
2(\mathrm{OH})^{-}\end{array}$ \\
\hline $\begin{array}{l}\text { Molten } \\
\text { carbonate }\end{array}$ & $\begin{array}{l}\mathrm{H}_{2}+\mathrm{CO}_{3}=\rightarrow \\
\mathrm{H}_{2} \mathrm{O}+\mathrm{CO}_{2}+ \\
2 \mathrm{e}^{-} \\
\mathrm{CO}+\mathrm{CO}_{3}=\rightarrow \\
2 \mathrm{CO}_{2}+2 \mathrm{e}^{-}\end{array}$ & $\begin{array}{l}\frac{1}{2} \mathrm{O}_{2}+\mathrm{CO}_{2} \\
+\quad 2 \mathrm{e}^{-} \rightarrow \\
\mathrm{CO}_{3}{ }^{=}\end{array}$ \\
\hline $\begin{array}{l}\text { Solid } \\
\text { Oxide }\end{array}$ & $\begin{array}{l}\mathrm{H}_{2}+\mathrm{O}^{=} \rightarrow \mathrm{H}_{2} \mathrm{O} \\
+2 \mathrm{e}^{-} \\
\mathrm{CO}+\mathrm{O}^{=} \rightarrow \\
\mathrm{CO}_{2}+2 \mathrm{e}^{-} \\
\mathrm{CH}_{4}+4 \mathrm{O}^{=} \rightarrow \\
2 \mathrm{H}_{2} \mathrm{O}+\mathrm{CO}_{2}+ \\
8 \mathrm{e}^{-}\end{array}$ & $\begin{array}{l}\frac{1}{2} \mathrm{O}_{2}+2 \mathrm{e} \\
\rightarrow \mathrm{O}^{=}\end{array}$ \\
\hline
\end{tabular}

(Sumber: Aryani, Dharma, 2008)

Material berbasis polimer memiliki beberapa keunggulan:

- Mempunyai hantaran yang cocok untuk aplikasi sel eletrokimia.

- Mempunyai hantaran listrik yang rendah.

- Mempunyai sifat mekanik yang baik.

- Mempunyai kestabilan kimia, elektrokimia dan fotokimia yang baik.

- Murah dalam pembuatannya.

Disebut Proton Exchange Membrane (PEM), karena menggunakan proton sebagai konduktor untuk melewati membran dari bahan polimer yang berfungsi sebagai elektrolit dari anoda ke katoda. Katalisator yang digunakan adalah platina. Lihat gambar 3. 


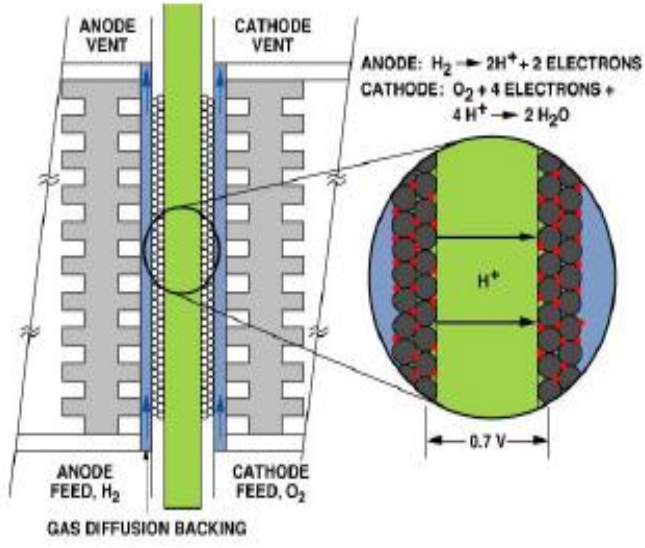

Gambar 3. Skematik PEMFC

(Sumber: Aryani, Dharma, 2008)

Struktur satu unit PEMFC yang terdiri dari anoda, katoda serta membran, disebut Membrane Electrode Assembly (MEA). Bekerja pada suhu rendah $\left(60^{0}-80^{\circ}\right)$ dalam hidrogen murni dalam bentuk gas, yang dialirkan ke anoda dengan tekanan konstan. Hidrogen yang menyebar di anoda akan dibantu katalisator, dari bahan platina untuk melepaskan elektron menuju beban dan ion positif hidrogen (proton) yang akan dialirkan menuju katoda. Proton yang dipindahkan ke katoda melalui membran penghantar proton yang hanya membolehkan ion proton saja yang lewat dan menyaring elektron. Reaksi yang terjadi pada PEFC adalah sebagai berikut $[1,3]$;

Anoda $: \mathrm{H}_{2} \rightarrow 2 \mathrm{H}^{+}+2 \mathrm{e}^{-}$

Katoda : $\frac{1}{2} \mathrm{O}_{2}+2 \mathrm{H}^{+}+2 \mathrm{e}^{-} \rightarrow \mathrm{H}_{2} \mathrm{O}$

Reaksi keseluruhan : $\mathrm{H}_{2}+\frac{1}{2} \mathrm{O}_{2} \rightarrow \mathrm{H}_{2} \mathrm{O}$ (air)

+ Panas

\section{PEMFC HORIZON H-100}

PEMFC Horizon H-100 ini merupakan jenis fuel cell komersil yang diproduksi oleh Horizon. Fuel cell ini memiliki kapasitas daya sebesar 100 watt. Fuel cell ini memiliki saluran masukan dan keluaran gas H2, sedangkan untuk saluran oksigennya hanya dialirkan dari blower.

Gambar bagian-bagian sistem PEMFC H-100 dapat dilihat pada gambar 4 .

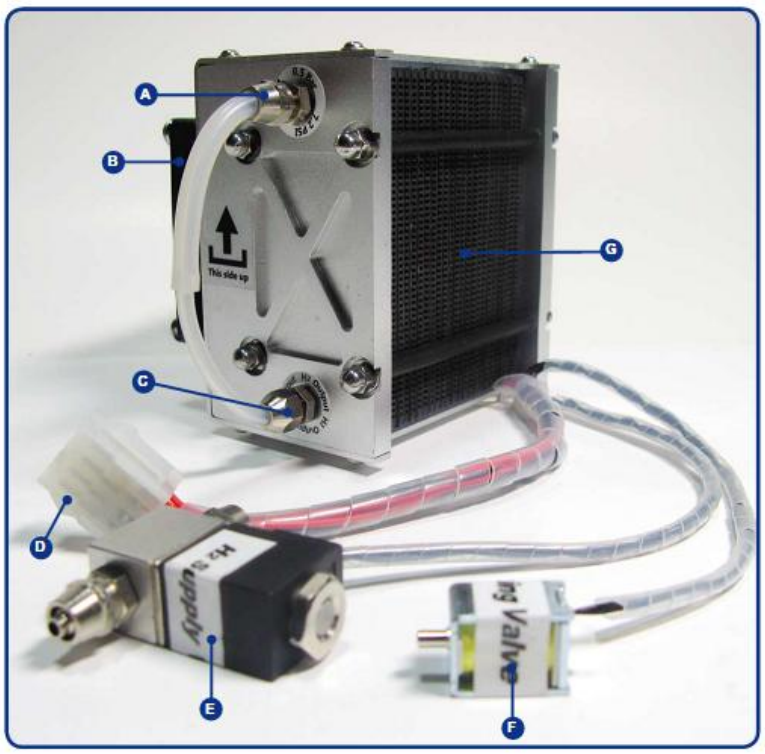

(a)

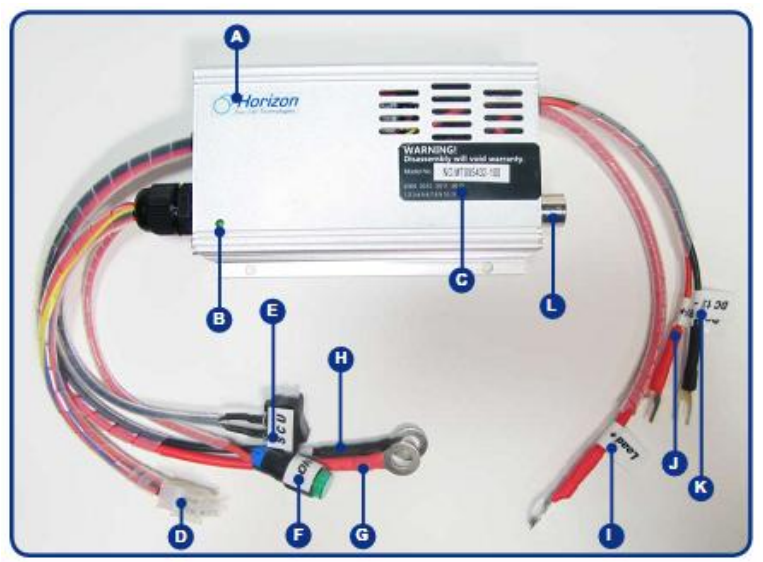

(b)

Gambar 4. Bagian-bagian PEMFC H-100

(a) Stack, valve masukan, valve purging, blower.

(b) Kontroller, saklar on/off, SCU

(H-100 Fuel Cell Stack User Manual,

$$
\text { V2.0, 2009) }
$$

\section{1) Stack}

Stack adalah komponen utama dari sebuah fuel cell. Pada komponen ini terdapat membran polymer, lempeng anoda dan katoda, saluran input dan output $\mathrm{H} 2$, konektor output, blower serta kabel konektor ke kontroller. Di dalam stack inilah terjadi reaksi gas $\mathrm{H} 2$ dengan oksigen melalui membran polymer sehingga menguraikan gas $\mathrm{H} 2$ menjadi 
ion dan akan menghasilkan aliran elektron.

\section{2) H2 Supply Valve}

Valve ini berfungsi untuk membuka aliran gas $\mathrm{H} 2$ dari tabung gas ke stack, jadi valve ini terletak sebelum input stack. Saat sistem hidup maka valve ini juga bekerja, dan ketika sistem mati valve ini juga mati. Valve ini tidak dapat diatur bukaannya, jadi hanya berfungsi on off saja.

3) H2 Purge Valve

Valve purging berfungsi membuang sisa reaksi gas dari dalam stack, berupa air dan gas sisa. Valve ini akan hidup secara periodik, yaitu 1 kali dalam 10 detik. Selain itu valve ini juga berfungsi untuk menjaga kestabilan tegangan keluaran fuel cell, dimana valve ini akan membuang gas $\mathrm{H} 2$ yang telah jenuh, dan kemudian diganti dengan gas yang baru sehingga akan merefresh tegangan keluarannya.

4) Blower

Berfungsi untuk mengalirkan $\mathrm{O} 2$ ke sistem serta untuk mengurangi panas pada sistem. Blower ini hanya akan hidup jika sistem juga hidup.

\section{5) Controller}

Berfungsi untuk mengontrol suhu stack, kipas, hidrogen input, purging dan scu. Selain itu controller ini juga berfungsi sebagai pengaman sistem ketika beban lebih besar dari kapasitas maka sistem akan turn off.

\section{6) On/Off Switch}

Saklar ini digunakan untuk mematikan atau menghidupkan sistem. Penggunaannya dengan cara menekan tombolnya selama \pm 5 detik.

\section{7) Short Circuit Unit}

Saklar ini berfungsi untuk mematikan sistem dengan cepat. Saklar ini hanya digunakan jika dibutuhkan.

\section{Karakteristik Power PEMFC H-100}

Grafik karakteristik power PEMFC $\mathrm{H}$ 100 ditunjukkan pada gambar 5. sampai dengan gambar 7. Grafik karakteristik ini diperoleh dari data spesifikasi yang disertakan dalam user manual Horizon $\mathrm{H}$ 100.

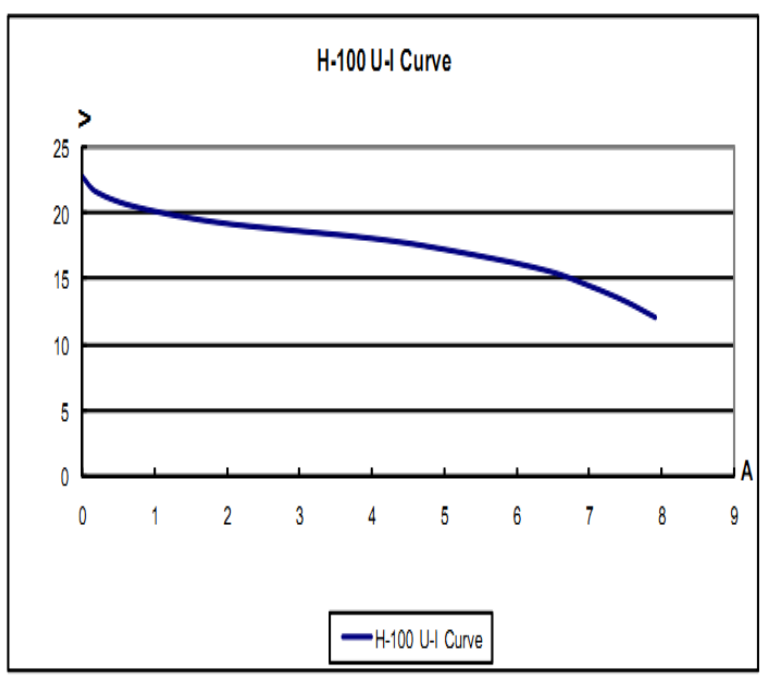

Gambar 5. Grafik Arus terhadap Tegangan

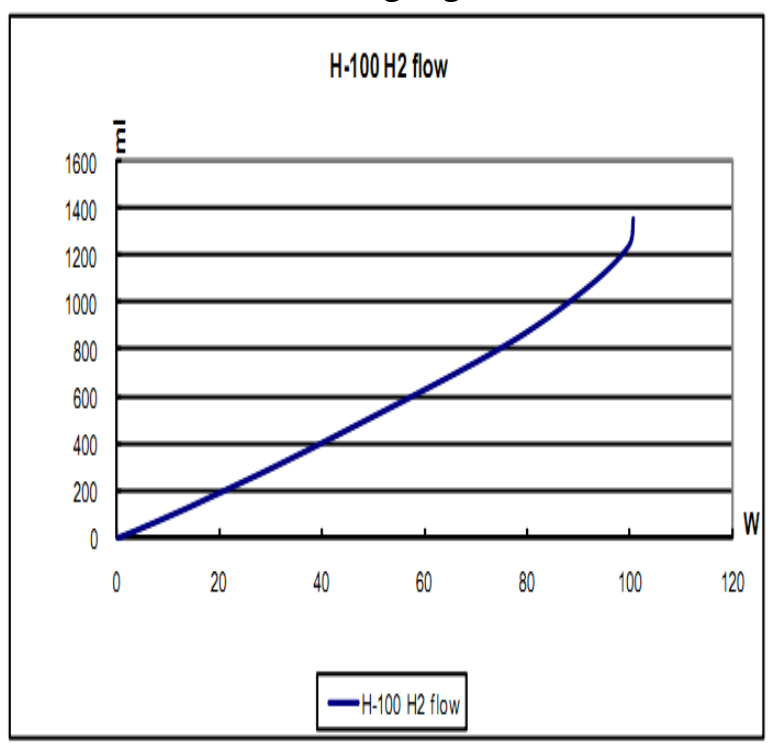

Gambar 6. Grafik Daya terhadap Aliran 


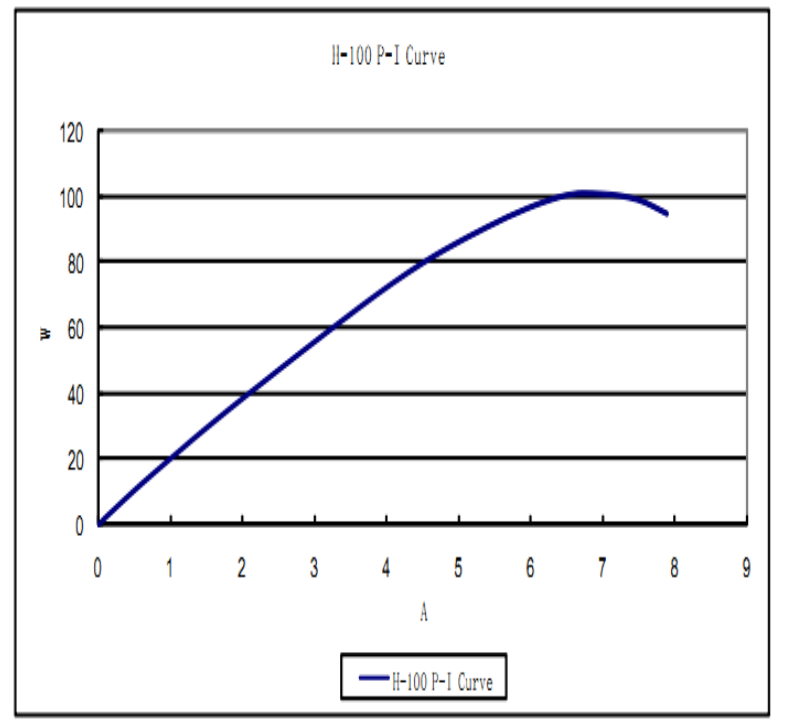

Gambar 7. Grafik Arus terhadap Daya

\section{Spesifikasi PEMFC H-100}

Tabel 2 menunjukkan spesifikasi teknis dari PEMFC H-100 yang diperoleh dari user manual.

Tabel 2. spesifikasi teknis dari PEMFC H-

\section{0}

\begin{tabular}{|c|c|}
\hline Type of fuel cell & PEM \\
\hline Number of cells & 24 \\
\hline Rated power & $100 \mathrm{~W}$ \\
\hline Rated performance & 14V@7.2A \\
\hline Output voltage range & $13 \mathrm{~V}-23 \mathrm{~V}$ \\
\hline Weight (with fan \& casing) & $0.95 \mathrm{~kg}(201 \mathrm{lbs})$ \\
\hline Size & $143 \times 109 \times 94 \mathrm{~mm}(5.6 \times 4.3 \times 3.7)$ \\
\hline Reactants & Hydrogen and Air \\
\hline Rated H2 consumption & $1.41 / \mathrm{min}\left(83 \mathrm{in}^{3} / \mathrm{min}\right)$ \\
\hline Hydrogen pressure & $0.4-0.45 \mathrm{Bar}(5.8-6.5 \mathrm{PSI})$ \\
\hline Controller weight & $0.4 \mathrm{~kg}(0.88 \mathrm{lbs})$ \\
\hline Hydrogen supply valve voltage & $12 \mathrm{~V}$ \\
\hline Purging valve voltage & $12 \mathrm{~V}$ \\
\hline Blower voltage & $12 \mathrm{~V}$ \\
\hline Ambient temperature & $5.35^{\circ} \mathrm{C}\left(41.95^{\circ} \mathrm{F}\right)$ \\
\hline Max stack temperature & $65^{\circ} \mathrm{C}\left(149^{\circ} \mathrm{F}\right)$ \\
\hline Hydrogen purity & $99.999 \%$ dry H2 \\
\hline Humidification & Self-humidified \\
\hline Cooling & Air (integrated cooling fan) \\
\hline Start up time & Immediate \\
\hline Efficiency of system & 40\%@14V \\
\hline
\end{tabular}

(H-100 Fuel Cell Stack User Manual, V2.0, 2009)

\section{METODOLOGI}

Gambar 8 merupakan gambar blok diagram percobaan sistem PEMFC H-100. Gambar yang ditandai dengan garis putusputus merupakan bagian yang ditambahkan pada sistem. Tegangan masukan driver diatur melalui PC.

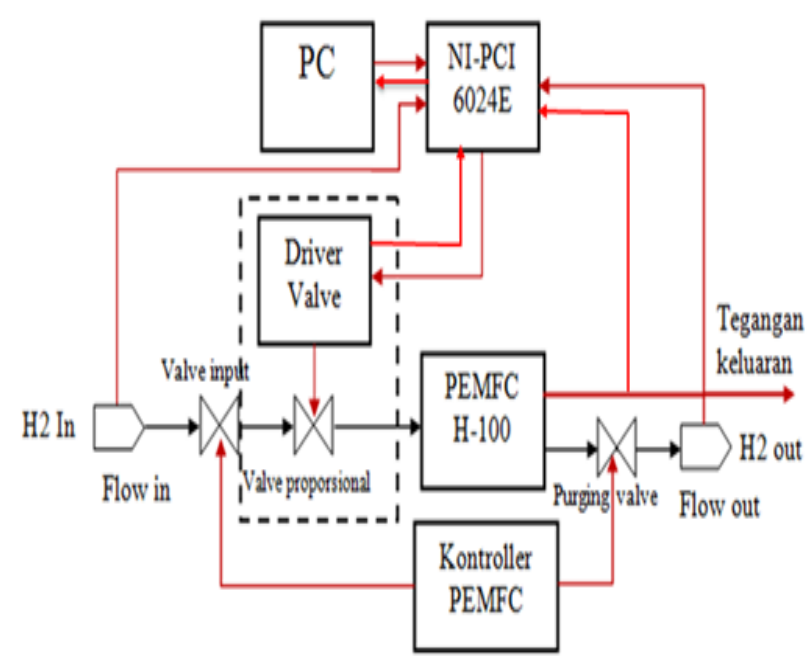

Gambar 8. Blok diagram percobaan sistem PEMFC dengan bukaan valve maksimum dan optimum.

Percobaan pertama dilakukan dengan memberikan masukan driver valve pada nilai maksimum sehingga bukaan valve juga maksimum. Percobaan kedua dilakukan dengan mengubah masukan driver valve ke nilai optimum sesuai dengan beban yang sedang terhubung ke sistem. Tegangan masukan driver ini nilainya akan naik seiring naiknya beban. Percobaan dilakukan dengan bantuan program simulink matlab dengan sample time 0.01 selama 90 detik. Selama percobaan, data tegangan masukan driver valve dan daya beban direkam untuk keperluan analisa

\section{Karakteristik hubungan masukan driver valve terhadap daya beban pada sistem PEMFC H-100.}

Berdasarkan data yang didapatkan dari hasil percobaan dengan bukaan valve optimum, didapatkan karakteristik hubungan tegangan masukan optimum driver valve terhadap daya 
beban pada sistem PEMFC H-100, yang ditunjukkan pada gambar 9 .

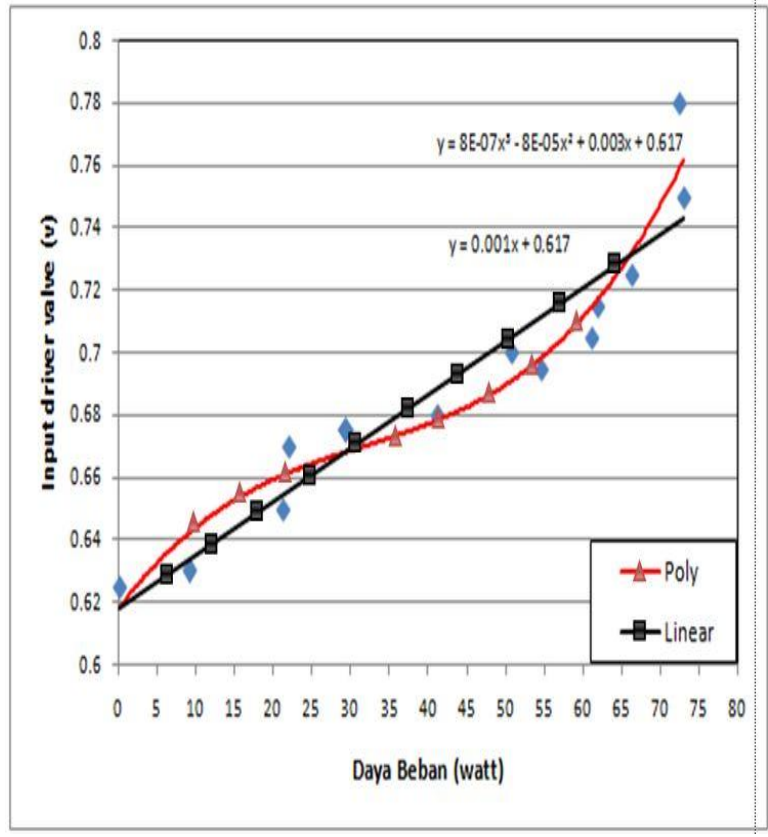

Gambar 9. Karakteristik hubungan tegangan optimum masukan driver valve terhadap daya beban.

Dari grafik pada gambar 9, ada dua persamaan yang didapatkan, yaitu persamaan linier dan persamaan polinomial. Keluaran sistem PEMFC H-100 berupa daya beban dijadikan masukan dalam persamaan, hasilnya dijadikan masukan driver sehingga bukaan valve proporsional berubah sesuai dengan perubahan daya beban.

persamaan:

a. Polinomial

$$
y=8 E-07 x^{3}-8 E-05 x^{2}+0.003 x+0.617
$$

b. Linier

$$
y=0.001 x+0.617
$$

keterangan:

$\mathrm{y}=$ masukan driver valve $(\mathrm{Vdc})$

$\mathrm{x}=$ daya beban (watt)

Persamaan linier ini didapatkan dengan bantuan tool chart pada program excell 2007.

\section{Blok diagram pengaturan valve masukan gas $\mathrm{H}_{2}$ pada sistem PEMFC}

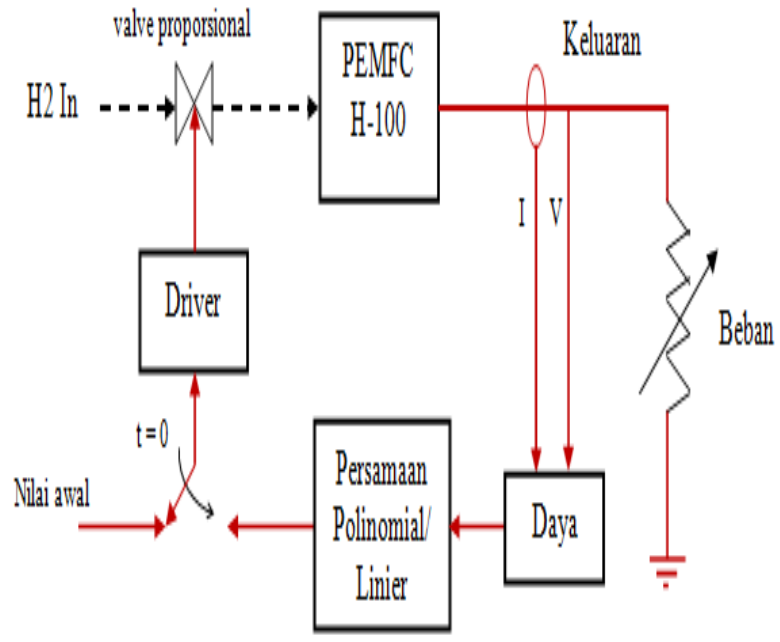

Gambar 10. Blok diagram kendali pengujian sistem PEMFC H-100

Pada gambar 10 terlihat blok diagram kendali sistem pengujian sistem dengan bukaan valve secara otomatis sesuai dengan perubahan daya beban. Daya beban yang merupakan hasil perkalian arus dan tegangan keluaran sistem akan dimasukkan dalam persamaan, hasilnya akan dijadikan masukan driver valve. Sebelum pengujian dijalankan, tegangan masukan driver diatur pada nilai awal maksimum. Saat pengujian dijalankan, tegangan masukan driver diambil alih oleh keluaran persamaan.

Pengujian dilakukan dengan mengubah beban yang terhubung pada sistem secara bertahap, mulai dari tanpa beban sampai dengan beban maksimum. Setiap perubahan beban data tegangan, arus, aliran masukan dan keluaran gas $\mathrm{H} 2$ nya direkam untuk keperluan analisa.

\section{Langkah-langkah pengujian}

1. Buka valve utama pada tabung gas $\mathrm{H} 2$ dan atur pada tekanan $40 \mathrm{kpa}$.

2. Buka program simulink, tegangan input driver valve diatur pada nilai $5 \mathrm{Vdc}$ (max).

3. Hidupkan sistem PEMFC H-100 sesuai buku petunjuk.

4. Setelah sistem hidup, berikan beban secara bertahap mulai dari tanpa beban hingga beban maksimum.

5. Setelah diberikan beban, jalankan simulink. Pengujian dengan simulink 
dilakukan dengan sample time 0,01 detik selama 90 detik.

6. Pengujian dilakukan dengan dua persamaan, yang pertama persamaan polinomial dan yang kedua persamaan linier.

7. Pada setiap pengujian, data arus dan tegangan keluaran, aliran gas input/output dan tegangan input driver valve proporsional direkam untuk keperluan analisa.

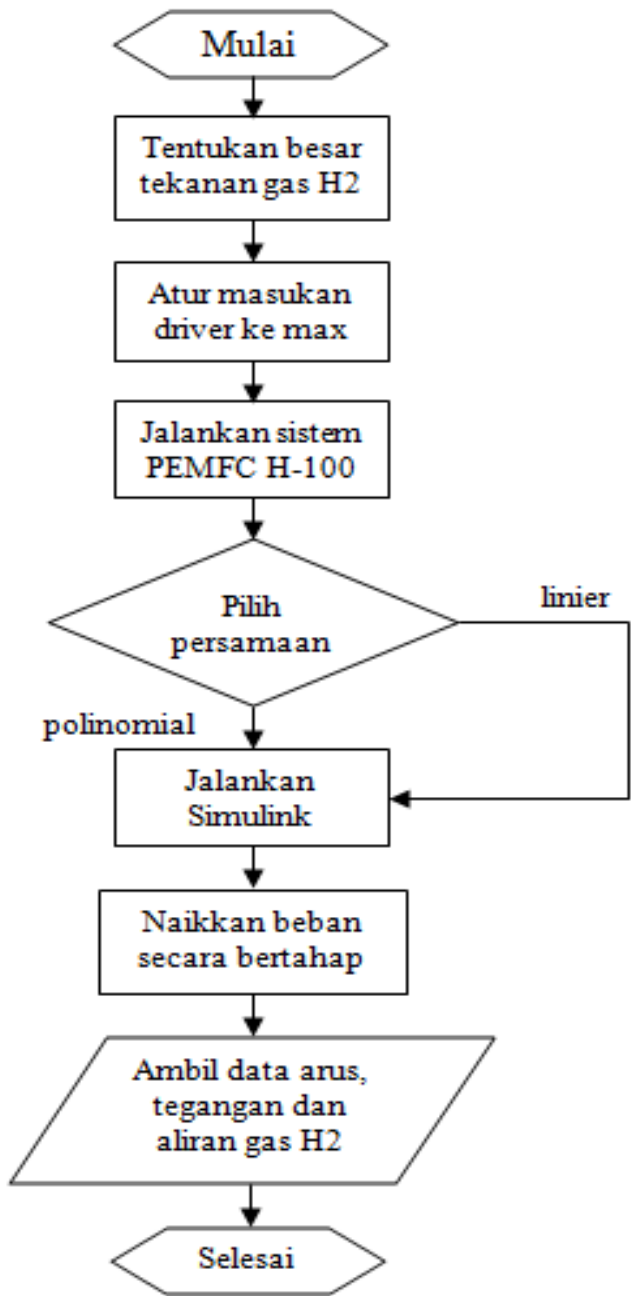

Gambar 11. Diagram alir langkah-langkah pengujian sistem PEMFC H-100

Diagram alir pengujian sistem PEMFC pada bukaan valve berdasarkan persamaan polinomial dan linier dapat dilihat pada gambar 11.

\section{HASIL DAN PEMBAHASAN}

Tegangan dan arus keluaran sistem PEMFC.

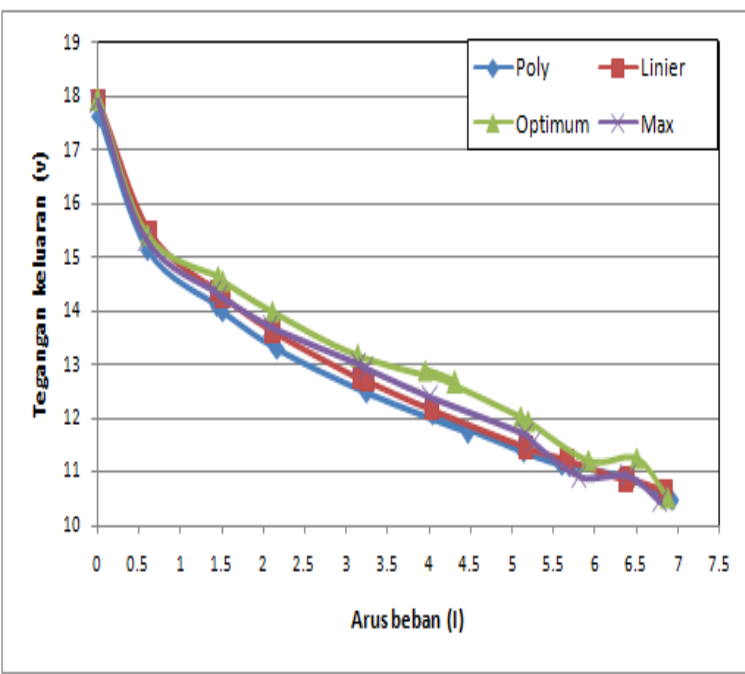

Gambar 12. Karakteristik tegangan terhadap arus beban pada persamaan polinomial, linier, bukaan valve maksimum dan optimum.

Dari gambar 12 terlihat ada perbedaan pada karakteristik tegangan keluaran fuel cell terhadap arus beban pada bukaan valve berdasarkan persamaan polinomial dan linier. Perbedaan ini disebabkan karena kondisi sistem saat pengujian yang berbeda. Idealnya karakteristik tegangan keluaran sistem terhadap arus beban pada kedua pengujian harusnya sama. Intinya jika sistem masih dalam keadaan hidup maka performance pada kedua pengujian seharusnya memiliki karakteristik yang sama.

\section{Pemakaian gas $\mathrm{H} 2$ pada sistem PEMFC H-100}

Pada gambar 13 dapat dilihat bahwa aliran masukan gas $\mathrm{H} 2$ pada sistem PEMFC H-100 pada pengujian bukaan valve proporsional menggunakan persamaan polinomial dan linier menunjukkan perbedaan yang sangat kecil, yaitu sekitar \pm 0.0004 LPM. Aliran masukan gas H2 dengan bukaan valve persamaan linier lebih tinggi dibandingkan dengan persamaan polinomial. Perbedaan ini mulai terlihat pada saat beban 50 sampai 90 watt. 


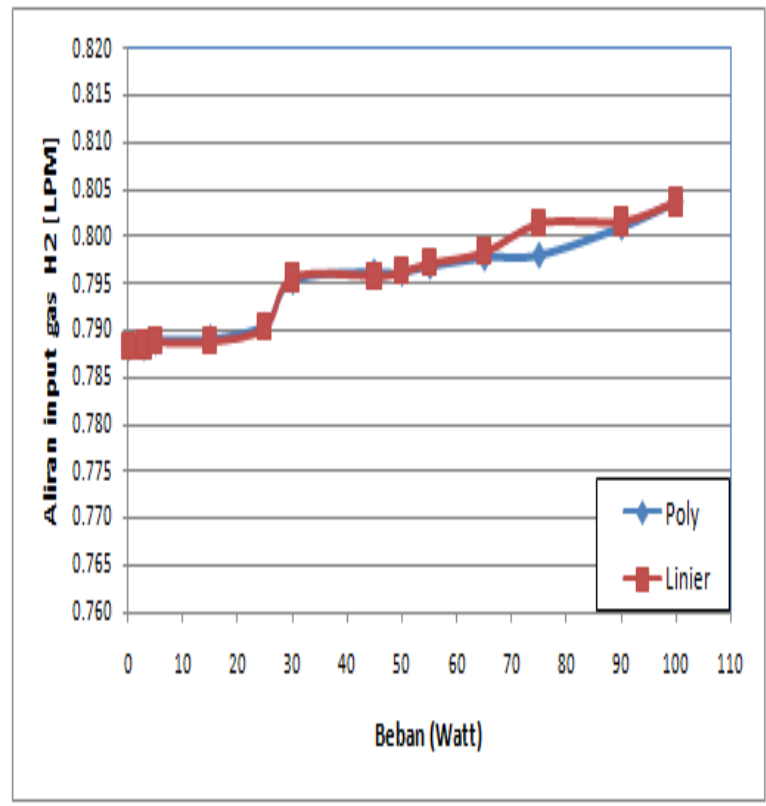

Gambar 13. Perbandingan aliran masukan gas $\mathrm{H} 2$ terhadap beban pada pengujian dengan persamaan polinomial dan linier

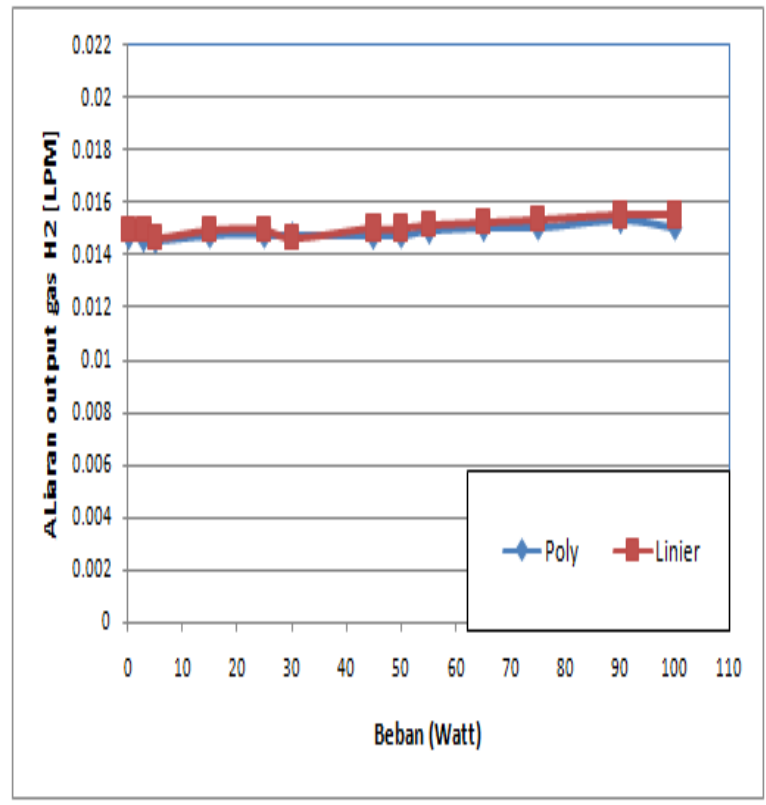

Gambar 14. Perbandingan aliran keluaran gas $\mathrm{H} 2$ terhadap beban pada pengujian dengan persamaan polinomial dan linier

Gambar 14 menunjukkan perbandingan aliran keluaran gas $\mathrm{H} 2$ terhadap beban antara pengujian sistem dengan bukaan valve menggunakan persamaan polinomial dan linier. Dari gambar 14 terlihat bahwa aliran keluaran gas $\mathrm{H} 2$ pada pengujian dengan persamaan polinomial rata-rata lebih kecil \pm 0.00024 LPM dibandingkan dengan persamaan linier.

Pengukuran aliran output gas $\mathrm{H} 2$ pada sistem PEMFC H-100 ini bertujuan untuk melihat berapa besar gas $\mathrm{H} 2$ yang bereaksi dalam sistem. Semakin besar aliran keluaran gas $\mathrm{H} 2$ maka jumlah gas $\mathrm{H} 2$ yang bereaksi semakin sedikit sehingga pemakaian gas $\mathrm{H} 2$ menjadi boros. Sebaliknya jika aliran kelauaran gas $\mathrm{H} 2$ semakin kecil berarti konsumsi gas $\mathrm{H} 2$ menjadi lebih hemat.

\section{Perbandingan tingkat penghematan gas H2 pada sistem PEMFC H-100}

Tingkat penghematan di sini maksudnya adalah rasio daya beban dengan aliran masukan gas $\mathrm{H} 2$ pada sistem PEMFC H-100. Perbandingan tingkat penghematan gas $\mathrm{H} 2$ pada pengujian sistem PEMFC H-100 terhadap beban dengan bukaan valve menggunakan persamaan polinomial dan linier dapat dilihat pada gambar 15 .

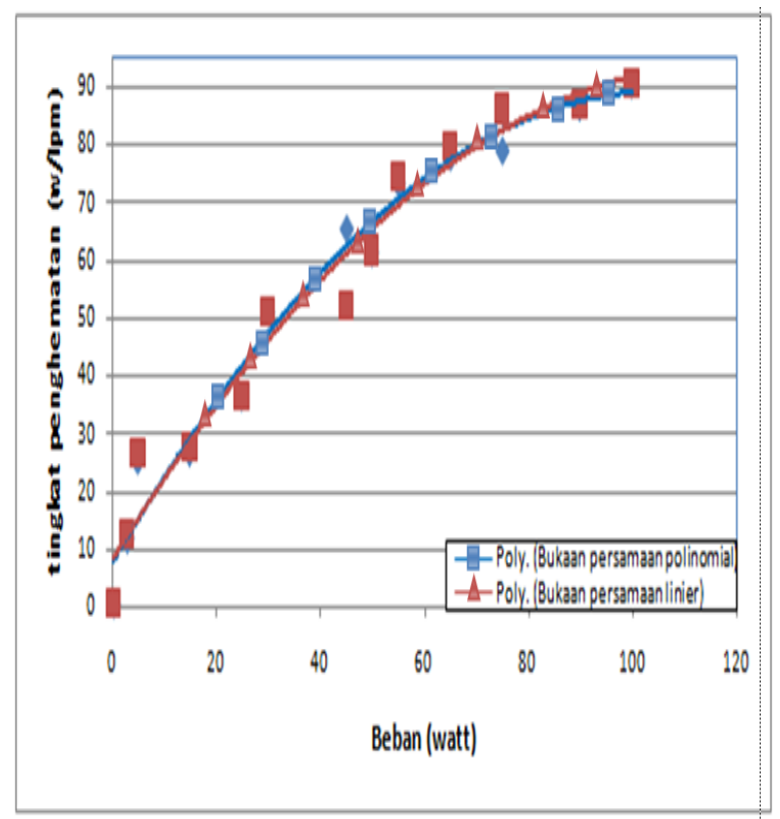

Gambar 15. Perbandingan tingkat penghematan gas $\mathrm{H} 2$ pada sistem PEMFC dengan bukaan valve menggunakan persamaan polinomial dan linier

Dari gambar 15. terlihat bahwa tingkat penghematan gas $\mathrm{H} 2$ menggunakan persamaan linier lebih tinggi dibandingkan 
menggunakan persamaan polinier pada beban di atas 50 watt. Pada beban di atas 70 watt, tingkat penghematan gas $\mathrm{H} 2$ menggunakan persamaan linier rata-rata lebih tinggi 1.6 ppm dibandingkan menggunakan persamaan persamaan polinomial.

\section{Pengontrolan bukaan valve dengan persamaan linier}

Dari hasil pengujian dinamik sistem PEMFC H-100 terlihat bahwa kedua persamaan dapat mengatur bukaan valve sesuai dengan besar daya beban yang terhubung ke sistem. Namun untuk selanjutnya persamaan linier yang akan digunakan untuk dijadikan algoritma dalam mengatur bukaan valve proporsional pada masukan gas H2 sistem PEMFC H-100.

Karena hasil dari grafik daya beban per aliran masukan gas $\mathrm{H} 2$ pada bukaan valve menggunakan persamaan linier memiliki efisiensi yang lebih rendah dari bukaan valve optimum maka nilai pada persamaan linier diturunkan menjadi:

$$
\begin{aligned}
& \mathrm{y}=0.0017 \mathrm{x}+0.45 \\
& \text { dimana; } \\
& \mathrm{x}=\text { daya beban (watt) } \\
& \mathrm{y}=\text { masukan driver valve (vdc) }
\end{aligned}
$$

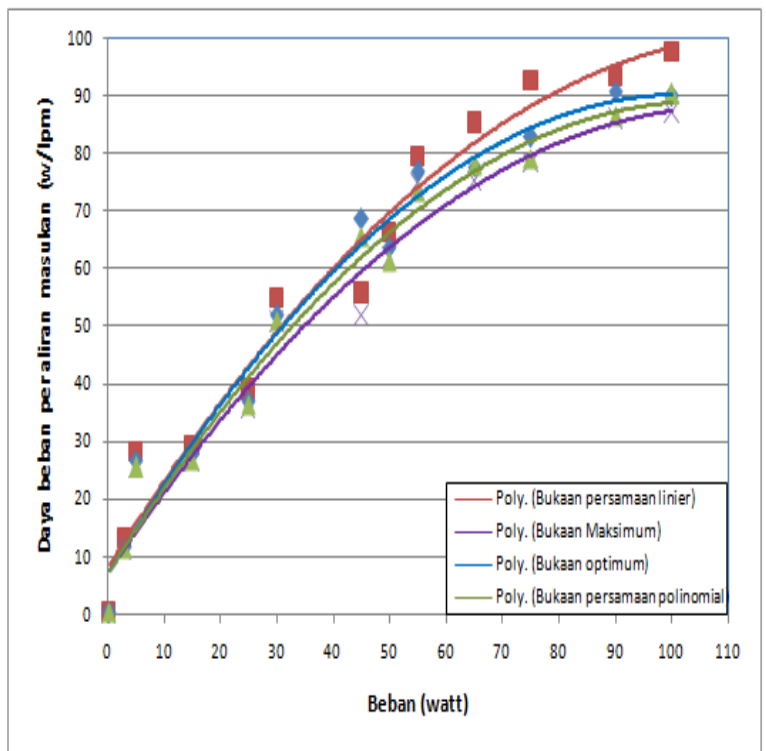

Gambar 16. Perbandingan daya beban per aliran masukan gas $\mathrm{H} 2$ pada sistem PEMFC H-100 terhadap beban dengan bukaan valve optimum, maksimum, bukaan dengan persamaan polinomial dan linier yang baru
Batasan minimum masukan driver ditetapkan pada nilai 0.45 vdc dan batas maksimum pada nilai 2 vdc. Hal ini untuk menjaga agar sistem masih mendapat suplay gas yang cukup dan tidak boros. Dengan mengunakan persamaan linier yang baru didapatkan perbandingan daya beban per aliran masukan gas $\mathrm{H} 2$ terhadap beban yang lebih tinggi dibandingkan dengan bukaan valve optimum seperti yang terlihat pada gambar 16.

\section{SIMPULAN}

Dari pengujian yang dilakukan dapat disimpulkan :

1. Persamaan pada grafik karakteristik hubungan tegangan optimum driver valve terhadap daya beban dapat dijadikan sebagai kontrol untuk mengatur bukaan valve input gas $\mathrm{H} 2$ sistem PEMFC $\mathrm{H}-100$ secara otomatis sesuai dengan perubahan daya beban.

2. Pengujian dengan bukaan valve menggunakan persamaan linier menunjukkan pemakaian gas $\mathrm{H} 2$ yang lebih kecil dibandingkan dengan persamaan linier untuk beban di atas 50 watt.

3. Dengan menurunkan nilai pada persamaan linier didapatkan tingkat penghematan gas $\mathrm{H} 2$ yang lebih tinggi, sehingga lebih hemat dalam konsumsi gas H2 tanpa mengurangi performa keluaran sistem secara signifikan.

\section{SARAN}

Penelitian yang telah dilakukan ini dapat dikembangkan dengan membuat sebuah kontroler untuk mengatur bukaan valve sehingga dapat mempermudah pengontrolan gas $\mathrm{H} 2$ pada sistem PEMFC

\section{DAFTAR PUSTAKA}

Aryani, Dharma. Identifikasi Sistem Proton Exchange Membrane Fuel Cell (PEMFC) dengan Metode Kuadrat Terkecil. Seminar, Universitas Indonesia. Desember 2008. 
Horizon Fuel Cell. H-100 Fuel Cell Stack User Manual. V2.0, 2009

Muzamir Isa, Baharuddin Ismail, Che Mat Hadzer, Ismail Daut and Faizah Abu Bakar. Characteristic Curve of a Fuel Cell. American Journal of Applied Sciences 3 (11): 2134-2135, 2006 ISSN 1546-9239. 